\title{
Pulmonary Function in HIV-Infected Recreational Drug Users in the Era of Anti- Retroviral Therapy
}

Joseph A Simonetti ${ }^{1^{*}}$, Matthew R Gingo ${ }^{2}$, Lawrence Kingsley ${ }^{3}$, Cathy Kessinger ${ }^{2}$, Lorrie Lucht ${ }^{2}$, Balasubramani GK ${ }^{4}$, Joseph K Leader ${ }^{5}$, Laurence Huang ${ }^{6}$, Ruth M Greenblatt ${ }^{6,9}$, John Dermand ${ }^{7}$, Eric C Kleerup ${ }^{7}$ and Alison Morris ${ }^{8}$

${ }^{1}$ Division of General Internal Medicine, Department of Medicine, University of Washington, Seattle, WA, USA

${ }^{2}$ Division of Pulmonary, Allergy and Critical Care Medicine, Department of Medicine, University of Pittsburgh, Pittsburgh, PA, USA

${ }^{3}$ Division of Infectious Diseases and Microbiology, Department of Medicine, University of Pittsburgh, Pittsburgh, PA, USA

${ }^{4}$ Department of Epidemiology, Graduate School of Public Health, University of Pittsburgh, Pittsburgh, PA, USA

5Imaging Research Division, Department of Radiology, University of Pittsburgh, Pittsburgh, PA, USA

${ }^{6}$ Department of Medicine, University of California San Francisco, San Francisco, CA, USA

${ }^{7}$ Division of Pulmonary and Critical Care Medicine, Department of Medicine, David Geffen School of Medicine, University of California Los Angeles, Los Angeles, CA, USA

${ }^{8}$ Department of Immunology, University of Pittsburgh, Pittsburgh, PA, USA

${ }^{9}$ Department of Clinical Pharmacy, University of California, San Francisco, CA, USA

*Corresponding author: Joseph A Simonetti, 1100 Olive Way, Suite 1400, Seattle WA, 98101, USA, Tel: 330714 1648, Fax: 206764 2935; E-mail: simonja@uw.edu Received date: Aug 07, 2014; Accepted date: Oct 24, 2014; Published date: Oct 29, 2014

Copyright: (c) 2014 Simonetti JA, et al. This is an open-access article distributed under the terms of the Creative Commons Attribution License, which permits unrestricted use, distribution, and reproduction in any medium, provided the original author and source are credited.

\section{Abstract}

Background: Individuals with HIV infection commonly have pulmonary function abnormalities, including airflow obstruction and diffusion impairment, which may be more prevalent among recreational drug users. To date, the relationship between drug use and pulmonary function abnormalities among those with HIV remains unclear.

Objective: To determine associations between recreational drug use and airflow obstruction, diffusion impairment, and radiographic emphysema in men and women with HIV.

Methods: Cross-sectional analysis of pulmonary function and self-reported recreational drug use data from a cohort of 121 men and 63 women with HIV. Primary outcomes were the presence (yes/no) of: 1) airflow obstruction, (pre- or post-bronchodilator forced expiratory volume in 1 second/forced vital capacity<0.70); 2 ) moderate diffusion impairment (diffusing capacity for carbon monoxide $<60 \%$ predicted); and 3 ) radiographic emphysema ( $>1 \%$ of lung voxels <-950 Hounsfield units). Exposures of interest were frequency of recreational drug use, recent (since last study visit) drug use, and any lifetime drug use. We used logistic regression to determine associations between recreational drug use and the primary outcomes.

Results: HIV-infected men and women reported recent recreational drug use at $56.0 \%$ and $31.0 \%$ of their study visits, respectively, and $48.8 \%$ of men and $39.7 \%$ of women reported drug use since their last study visit. Drug use was not associated with airway obstruction or radiographic emphysema in men or women. Recent crack cocaine use was independently associated with moderate diffusion impairment in women (odds ratio 17.6; $95 \%$ confidence interval 1.3-249.6, $\mathrm{p}=0.03$ ).

Conclusions: In this cross-sectional analysis, we found that recreational drug use was common among HIVinfected men and women and recent crack cocaine use was associated with moderate diffusion impairment in women. Given the increasing prevalence of HIV infection, any relationship between drug use and prevalence or severity of chronic pulmonary diseases could have a significant impact on HIV and chronic disease management.

Keywords: HIV; COPD; Emphysema; Diffusion impairment; Drug use; Pulmonary function; Cocaine

\section{Introduction}

As advances in HIV treatment have led to longer life expectancies for those with access to recommended care [1-3], chronic pulmonary diseases (e.g., chronic obstructive pulmonary disease, pulmonary arterial hypertension) have become more prevalent $[4,5]$. Respiratory symptoms are common in persons with HIV infection [6], as are airflow obstruction and pulmonary diffusion impairment $[7,8]$. A recent analysis of $167 \mathrm{HIV}$-infected individuals found that 1 in $5 \mathrm{had}$ irreversible airflow obstruction while 2 in 3 had diffusion impairment [6].

Recent studies have demonstrated associations between tobacco and antiretroviral therapy (ART) use and airflow obstruction in those with HIV [6,7]. HIV infection is also an independent risk factor for impaired diffusion capacity in both men and women; though causes of this impairment remain unclear $[9,10]$. Potential mechanisms for these abnormalities include lung injury from opportunistic infections and 
altered microbial colonization, aberrant inflammatory responses associated with HIV infection and/or other pathogens, and the effects of chronic ART $[6,7,11,12]$.

Behavioral risk factors such as recreational drug use may also be important, as HIV-infected populations have a high prevalence of drug use [13-15]. Estimates of drug use among HIV-infected populations have varied significantly, depending on the time period and specific subgroup sampled [16-18]. Data from the National Survey of Drug Use and Health suggest that approximately $80 \%$ of HIVinfected persons in the U.S. have used a recreational drug at some point in their life, including $16 \%$ who reported using an intravenous drug [16]. Estimates of current marijuana use among HIV-infected persons in the U.S. have ranged from 12-23\% [19-21] and among a recent sample of HIV-infected men, more than $20 \%$ reported recent use of stimulants, including crack cocaine and methamphetamines [22].

Among the HIV-uninfected, a number of acute and chronic pulmonary complications of recreational drug use have been identified $[23,24]$. Heroin use is associated with an increased risk for pneumonia, as well as acute, non-cardiogenic pulmonary edema. Stimulant use, such as amphetamines, cocaine and crack cocaine, can cause pulmonary barotrauma and acute pulmonary edema or hemorrhage when used by inhalation. When used intravenously, the same drugs may lead to the development of pulmonary arterial hypertension or granulomatous responses due to reactions from particulate matter that often contaminate the injected drug. Though marijuana use is associated with acute bronchodilation and long-term side effects, such as chronic cough, wheezing, and sputum production $[25,26]$, no clear association between its use and serious pulmonary conditions has been identified [25].

Despite the relationship between recreational drug use and pulmonary complications in HIV-uninfected persons, the relationship between drug use and pulmonary function in those with HIV remains ill-defined [25-28]. Recent studies have identified a relationship between cocaine and marijuana use and reduced diffusing capacity in HIV-infected women [9], and a relationship between intravenous drug use and airflow obstruction in HIV-infected men and women [6]. Another study demonstrated that lung function decline among intravenous drug users may disproportionately affect those with low CD4 counts and high HIV RNA levels [29]. However, in-depth studies of drug use and lung function in HIV have not been done; nor has the relationship between drug use and radiographic emphysema been evaluated. The aim of this study was to determine associations between recreational drug use and airflow obstruction, diffusion impairment, and radiographic emphysema in men and women with HIV.

\section{Methods}

We conducted a cross-sectional analysis of 121 men and 63 women 18 years of age or older with documented HIV infection who were followed longitudinally within the Multicenter AIDS Cohort Study (MACS) [30] and the Women's Interagency HIV Study (WIHS) [31] cohorts. Participants were outpatients without acute respiratory illness who were recruited from the University of Pittsburgh, University of California Los Angeles, and University of California San Francisco to participate in the University of Pittsburgh Lung HIV Cohort. Participants were selected to reflect the distributions of tobacco use and prevalence of respiratory symptoms within the MACS and WIHS parent studies $[4,9,10,30]$. Participants completed questionnaires at the time of enrollment and at study follow-up appointments (approximately every 6 months), and completed pulmonary function testing (PFTs) and computed tomography (CT) examination between January 1, 2009 and February 15, 2012. Institutional review boards at each site approved this study, and all subjects provided written, informed consent.

\section{Participant characteristics}

We abstracted sociodemographic data from study questionnaires, including: age, gender, race/ethnicity, and marital and educational statuses. We used questionnaire data to identify tobacco use, alcohol consumption per week, history of bacterial or Pneumocystis jirovecii pneumonia, and use of ART, defined as use of three or more drugs from two or more categories [32]. We used self-reported data collected during study visits to identify comorbid asthma diagnosis and bronchodilator use in the previous 3 months. We identified a history of hepatitis $\mathrm{C}$ infection by questionnaire and serologic data collected during study visits, and abstracted HIV-specific clinical data from MACS and WIHS, including nadir and current CD4 counts, and current HIV RNA level.

\section{Recreational drug use}

We used questionnaire responses to characterize recent (since last study visit) or any lifetime use of recreational drugs, including: any intravenous drug, marijuana, crack (alkaloid cocaine), cocaine, and heroin. Drug use survey questions differed between cohorts; thus, we characterized methamphetamine use in women, and use of "uppers" (i.e., stimulants, including methamphetamines) and "poppers" (amyl nitrites) in men. We then created a proxy variable to estimate frequency of drug use by calculating the percentage of all study visits in which a participant reported recent drug use.

\section{Pulmonary function testing and computed tomography}

Participants completed PFTs according to American Thoracic Society guidelines to obtain pre- and post-bronchodilator spirometry, and diffusing capacity for carbon monoxide (DLCO) [33,34]. Hankinson [35] and Neas [36] equations were used for spirometry and DLCO percent predicted values, respectively. Both equations adjust for age, gender, height and race. Predicted DLCO was additionally adjusted for hemoglobin and carboxyhemoglobin.

Helical, non-contrasted, CT examinations were performed at the three institutions under similar protocols using 64-detector scanners with the subjects supine and holding their breath at end-inspiration. CT data were acquired at 120-peak kilovoltage and 100-milliampere seconds with images reconstructed using General Electric's "standard" or Siemens' "B31f” kernel at $0.625 \mathrm{~mm}$ or $0.75 \mathrm{~mm}$ section thickness. Voxels depicting the lung were segmented from the CT images [37]. Those with a Hounsfield unit (HU) value less than -950 were considered to represent emphysema based on the density mask approach $[38,39]$.

\section{Statistical analysis}

We analyzed participants from each cohort separately because of significant baseline differences in sociodemographic, clinical and recreational drug use characteristics. Primary outcomes were the presence of: 1) airflow obstruction, defined as a pre- or post- 
Citation: Simonetti JA, Gingo MR, Kingsley L, Kessinger C, Lucht L, et al. (2014) Pulmonary Function in HIV-Infected Recreational Drug Users in the Era of Anti-Retroviral Therapy. J AIDS Clin Res 5: 365. doi:10.4172/2155-6113.1000365

Page 3 of 7

bronchodilator forced expiratory volume in 1 second (FEV1)/forced vital capacity (FVC) $<0.70 ; 2)$ moderate diffusion impairment defined as DLCO $<60 \%$ predicted; and 3) radiographic emphysema ( $>1 \%$ of lung voxels $<-950 \mathrm{HU})$. We selected moderate diffusion impairment as an outcome because mild impairment (DLCO $<80 \%$ predicted) is highly prevalent in HIV-infected populations [6,11]. Independent variables of interest were frequency of recreational drug use, recent (yes/no) drug use, and any lifetime (yes/no) drug use. We used logistic regression to determine associations between sociodemographic, clinical, and drug use characteristics and the primary outcomes. In multivariable models, we included ART use and cumulative packyears of tobacco use as covariates based on their a priori clinical significance. We selected all other covariates based on significance in bivariate analyses $(\mathrm{p}<0.2)$. For all significant outcomes, we tested whether the association between drug use and the outcomes differed based on CD4 count and HIV RNA level by testing an interaction term that included current CD4 count, log HIV RNA level, and the independent variable.

Assuming an alpha level of 0.05 and $80 \%$ power, the minimum effect size required to detect a statistically significant result in the outcome was $11 \%$ and $16 \%$ in the MACS and WIHS cohorts, respectively. We analyzed all data using SAS Version 9.2 (SAS, Inc., Cary, NC).

\section{Results}

\section{Participant characteristics}

Of 121 HIV-infected men enrolled from the MACS cohort, the mean age was 53 and $78.5 \%$ reported current or former tobacco use (Table 1). Men had a median CD4 count of 575 cells/microliter (IQR 440-794), median HIV RNA level of $<40$ copies/mL, and $86.0 \%$ reported taking ART since their previous visit.

Of $63 \mathrm{HIV}$-infected women enrolled from the WIHS cohort, the mean age was 49 and $80.9 \%$ reported current or former tobacco use (Table 1). Women had a median CD4 count of 426 cells/microliter (IQR 264-677), median HIV RNA level of 102 copies/mL, and 81.0\% reported taking ART since their previous visit.

\section{Recreational Drug Use}

Men reported recent recreational drug use at $56.0 \%$ of all study visits and $48.8 \%$ reported using at least 1 drug since their previous visit (Table 1). A large proportion of men reported some lifetime use of marijuana $(81.0 \%)$, poppers $(71.1 \%)$, cocaine $(62.8 \%)$, and uppers $(38.8 \%)$, and $14.9 \%$ reported some lifetime use of intravenous drugs (Table 2).

Women reported recent recreational drug use at $31.0 \%$ of all study visits and $39.7 \%$ reported using at least 1 drug since their previous visit (Table 2). A large proportion of women reported some lifetime use of marijuana (82.5\%) and intravenous drugs (54.0\%) (Table 2).

\begin{tabular}{|l|l|l|}
\hline Characteristic & $\begin{array}{l}\text { (Men's) Multicenter } \\
\text { AlDS Cohort Study } \\
\text { (n=121) }\end{array}$ & $\begin{array}{l}\text { Women's Interagency } \\
\text { HIV Study (n=63) }\end{array}$ \\
\hline Age, mean (SD) & $53.1(7.5)$ & $49.1(8.9)$ \\
\hline Female, $\mathrm{n}(\%)$ & $0(0)$ & $63(100)$ \\
\hline Race, $\mathbf{n}(\%)$ & \multicolumn{2}{|l}{} \\
\hline
\end{tabular}

\begin{tabular}{|c|c|c|}
\hline White & $100(82.6)$ & $23(36.5)$ \\
\hline Black & $21(17.4)$ & $40(63.5)$ \\
\hline Hispanic, n (\%) & $3(2.5)$ & $5(7.9)$ \\
\hline Completed high school, $\mathrm{n}(\%)$ & $114(94.2)$ & $47(74.6)$ \\
\hline \multicolumn{3}{|l|}{ Marital status, $\mathbf{n}(\%)$} \\
\hline Never married & -- & $21(33.3)$ \\
\hline Married & -- & $22(34.9)$ \\
\hline Divorced or widowed & -- & $20(31.8)$ \\
\hline \multicolumn{3}{|l|}{ Alcohol consumption, $\mathrm{n}(\%)$} \\
\hline None & $69(57.0)$ & $38(60.3)$ \\
\hline 1-2 drinks per week & $22(18.2)$ & $16(25.4)$ \\
\hline$>2$ drinks per week & $30(24.8)$ & $9(14.3)$ \\
\hline \multicolumn{3}{|l|}{ Clinical History } \\
\hline $\begin{array}{l}\text { Number of study visits } \\
\text { attended, mean (SD) }\end{array}$ & $35(16.0)$ & $26(6.3)$ \\
\hline \multicolumn{3}{|l|}{ Tobacco use, $\mathbf{n}(\%)$} \\
\hline Never & $26(21.5)$ & 12 (19.1) \\
\hline Former & $58(47.9)$ & $23(36.5)$ \\
\hline Current & $37(30.6)$ & $28(44.4)$ \\
\hline $\begin{array}{l}\text { Cumulative pack-years } \\
\text { tobacco use, median (IQR) }\end{array}$ & $8.2(0-33.2)$ & $3.0(0.04-12.4)$ \\
\hline Asthma diagnosis, $\mathrm{n}(\%)$ & $15(12.4)$ & $22(34.9)$ \\
\hline $\begin{array}{l}\text { Bronchodilator use } \\
\text { previous } 3 \text { months, } n(\%)\end{array}$ & $12(9.9)$ & $11(17.5)$ \\
\hline Hepatitis C infection, n (\%) & $13(10.7)$ & $30(47.6)$ \\
\hline $\begin{array}{lr}\text { History of } & \text { bacterial or } \\
\text { Pneumocystis } & \text { jirovecii } \\
\text { pneumonia, } \mathrm{n}(\%) & \end{array}$ & $40(33.1)$ & $14(22.2)$ \\
\hline $\begin{array}{l}\text { ART use since last visit, } n \\
(\%)\end{array}$ & $104(86.0)$ & $51(81.0)$ \\
\hline $\begin{array}{l}\text { Current CD4 } \\
\text { median (IQR) }\end{array}$ & $575(440-794)$ & $426(264-677)$ \\
\hline $\begin{array}{l}\text { Nadir CD4 (cells } / \mu L) \text {, median } \\
\text { (IQR) }\end{array}$ & $269(155-358)$ & $159(65-286)$ \\
\hline $\begin{array}{l}\text { Current HIV RNA level } \\
\text { (copies/mL), median (IQR) }\end{array}$ & $<40(40-40)$ & $102(48-727)$ \\
\hline \multicolumn{3}{|l|}{ Recreational Drug Use } \\
\hline $\begin{array}{l}\text { Percentage of total visits } \\
\text { reporting recent drug use, } \\
\text { median \% (IQR) }\end{array}$ & $56(18-87)$ & $31(3-75)$ \\
\hline $\begin{array}{l}\text { Any drug use since last visit, } \\
\mathrm{n}(\%)\end{array}$ & $59(48.8)$ & $25(39.7)$ \\
\hline \multicolumn{3}{|l|}{ Pulmonary Function } \\
\hline Airflow obstruction & & \\
\hline
\end{tabular}




\begin{tabular}{|l|l|l|}
\hline $\begin{array}{l}\text { Post-BD FEV1/FVC ratio } \\
<0.70, \mathrm{n}(\%)\end{array}$ & $16(13.2)$ & $7(11.1)$ \\
\hline $\begin{array}{l}\text { Post-BD FEV1/FVC ratio, } \\
\text { mean (SD) }\end{array}$ & $0.78(0.08)$ & $0.78(0.07)$ \\
\hline Diffusion impairment & $53(84.1)$ \\
\hline $\begin{array}{l}\text { DLCO \% predicted <80\%, n } \\
\text { (\%) }\end{array}$ & $65(53.7)$ & $23(36.5)$ \\
\hline $\begin{array}{l}\text { DLCO \% predicted <60\%, n } \\
\text { (\%) }\end{array}$ & $16(13.2)$ & $65(14.0)$ \\
\hline $\begin{array}{l}\text { DLCO \% predicted, mean } \\
\text { (SD) }\end{array}$ & $79(19.0)$ & $9(15.3)$ \\
\hline $\begin{array}{l}\text { Radiographic emphysema,b } \\
\mathrm{n}(\%)\end{array}$ & $64(65.3)$ & \\
\hline
\end{tabular}

Table 1: HIV: Human Immunodeficiency Virus; SD: Standard Deviation; IQR: Interquartile Range; ART: Antiretroviral Therapy; $\mu \mathrm{L}$ : Microliter; BD: Bronchodilator; FEV1: Forced Expiratory Volume in 1 second; FVC: Forced Vital Capacity; DLCO: Diffusing Capacity for Carbon Monoxide. aSurvey questions differ between MACS and WIHS. Unavailable data represented with "--“. bCT data available for 98 men and 59 women. Radiographic emphysema defined as $>1 \%$ of lung voxels $<-950$ Hounsfield units.

\section{Recreational drug use and airflow obstruction}

Airflow obstruction was present in $13.2 \%$ of men and $11.1 \%$ of women (Table 1). In bivariate and multivariable analyses, there were no statistically significant associations between recent, frequent or lifetime recreational drug use and airflow obstruction in men or women (Table 2). In multivariable analyses, men who reported recent marijuana use were somewhat more likely to have airflow obstruction (odds ratio $[\mathrm{OR}] 2.8 ;$ 95\% confidence interval [CI] 0.9-8.0; $\mathrm{p}=0.06$ ).

\section{Recreational drug use and moderate diffusion impairment}

Moderate diffusion impairment was present in $13.2 \%$ of men and $36.5 \%$ of women (Table 1). In bivariate analyses, there were no statistically significant associations between recent, frequent or lifetime recreational drug use and moderate diffusion impairment in men (Table 2). Women who reported any lifetime use of intravenous drugs were somewhat more likely to have moderate diffusion impairment (OR 2.8; 95\% CI 0.9-8.3; p=0.06) and women who reported recent crack use were more likely to have moderate diffusion impairment (OR 20.8; 95\% CI 2.4-180.8; $\mathrm{p}<0.01$ ).

In multivariable analyses, there were no statistically significant associations between recent, frequent or lifetime recreational drug use and moderate diffusion impairment in men (Table 2). In multivariable analyses that adjusted for ART use, cumulative pack-years of tobacco use, marital status, hepatitis $\mathrm{C}$ infection, and history of bacterial or Pneumocystis pneumonia, women who reported recent crack use were more likely to have moderate diffusion impairment (OR 17.6; 95\% CI 1.3-249.6; $\mathrm{p}=0.03$ ). There was no statistically significant interaction between recent crack use and current CD4 count and log HIV RNA levels.

\section{Recreational drug use and radiographic emphysema}

Radiographic emphysema was present in $65.3 \%$ of 98 men and $15.3 \%$ of 59 women with available CT data (Table 1). In bivariate and multivariable analyses, there were no statistically significant associations between recent, frequent or lifetime recreational drug use and radiographic emphysema in men or women (Table 2).

\section{Discussion}

In this cross-sectional analysis of 121 men and 63 women with HIV, we found that recreational drug use, and lung function abnormalities, such as airflow obstruction, moderate diffusion impairment, and radiographic emphysema were all common. Overall, approximately 1 in 10 had clinical airflow obstruction, while $13 \%$ of men and $37 \%$ of women had moderate diffusion impairment, and $65 \%$ of men and $15 \%$ of women had radiographic evidence of emphysema. We also observed an independent association between recent crack cocaine use and moderate diffusion impairment in women, and no relationship between drug use and airway obstruction or radiographic emphysema in either cohort.

While the causes of diffusion impairment in HIV-uninfected persons have been well documented (e.g., emphysema, pulmonary vascular disease), the mechanism by which diffusion impairment develops in those with HIV remains unclear. We have previously shown that cocaine use is associated with a worse absolute diffusing capacity in women, but the relationship was not examined in detail, nor had this relationship been evaluated in men with HIV [9]. This study adds to a growing body of evidence suggesting that cocaine exposure has a unique impact on diffusion abnormalities in HIVinfected persons [11,40]. However, whether cocaine exposure accelerates or independently causes these diffusion abnormalities remains unclear. In vitro models have suggested that cocaine exposure has an additive effect on endothelial injury and dysfunction in persons with HIV [41]. Pulmonary vascular disease, which is more common among women and those with HIV, may have contributed to the diffusion impairment in this cohort [42], and perhaps, cocaine exposure causes diffusion impairment through an additive or synergistic relationship with HIV-induced pulmonary hypertension. Additionally, cocaine exposure through smoking crack cocaine may cause this damage through direct toxicity. Importantly, crack cocaine use was not associated with radiographic emphysema in this study, suggesting that the diffusion abnormalities in this group were not secondary to emphysema. Notably, the association between cocaine use and diffusion impairment remains unclear even in HIV-uninfected populations [27,43-45].

There are several limitations of this study. First, we analyzed a relatively small, gender-stratified sample of participants who had a high prevalence of multi-substance use, which limited our ability to detect the independent effects of individual drugs. Second, the crosssectional nature of these analyses limits our ability to make causal inferences regarding the relationship between recreational drug use and the primary outcomes. Third, using available data, we created a proxy variable to estimate frequency of drug use. Given the complexity of drug use in this cohort, future analyses would benefit from detailed questionnaire data that precisely quantify frequency and quantity of drug use and delineate the complicated exposure histories of multisubstance users. Fourth, we did not account for duration or history of Pneumocystis prophylaxis, which may affect pulmonary function by altering microbial colonization and inflammation within pulmonary 
Citation: Simonetti JA, Gingo MR, Kingsley L, Kessinger C, Lucht L, et al. (2014) Pulmonary Function in HIV-Infected Recreational Drug Users in the Era of Anti-Retroviral Therapy. J AIDS Clin Res 5: 365. doi:10.4172/2155-6113.1000365

Page 5 of 7

tissue. Finally, most participants had relatively controlled HIV and more than $80 \%$ were on ART. These characteristics may have masked an interaction between drug use and lung function that differentially affects those with poorly controlled HIV, as a recent study of intravenous drug users showed that markers of poorly controlled HIV were associated with accelerated decline in both FEV1 and FVC [29]. Though we tested whether the relationship between drug use and the primary outcomes was dependent on CD4 cell count and viral load, this analysis was limited by our sample size.

\begin{tabular}{|c|c|c|c|c|c|c|c|c|}
\hline \multirow[b]{3}{*}{$\begin{array}{l}\text { Recreational Drug Use } \\
\text { Characteristic }\end{array}$} & \multicolumn{4}{|c|}{ (Men's) Multicenter AIDS Cohort Study } & \multicolumn{4}{|c|}{ Women's Interagency HIV Study } \\
\hline & \multicolumn{4}{|c|}{$n=121$} & \multicolumn{4}{|c|}{$\mathrm{n}=63$} \\
\hline & $\begin{array}{l}\text { Drug } \\
\text { Use }\end{array}$ & $\begin{array}{l}\text { Airflow } \\
\text { Obstruction }\end{array}$ & $\begin{array}{l}\text { Moderate } \\
\text { Diffusion } \\
\text { Impairment }\end{array}$ & $\begin{array}{l}\text { Radiographic } \\
\text { Emphysema }\end{array}$ & $\begin{array}{l}\text { Drug } \\
\text { Use }\end{array}$ & $\begin{array}{l}\text { Airflow } \\
\text { Obstruction }\end{array}$ & $\begin{array}{l}\text { Moderate } \\
\text { Diffusion } \\
\text { Impairment }\end{array}$ & $\begin{array}{l}\text { Radiographic } \\
\text { Emphysema }\end{array}$ \\
\hline & $\%$ & OR $(95 \% \mathrm{Cl})$ & OR $(95 \% \mathrm{Cl})$ & OR $(95 \% \mathrm{Cl})$ & $\%$ & OR (95\% Cl) & & \\
\hline $\begin{array}{l}\text { Percentage of total } \\
\text { visits reporting recent } \\
\text { drug usec }\end{array}$ & 56 & $1.41(1.00-1.98)$ & $1.04(0.77-1.40)$ & $1.07(0.85-1.36)$ & 31 & $1.19(0.78-1.82)$ & $1.17(0.88-1.55)$ & $1.07(0.72-1.59)$ \\
\hline Since last visit & $\mathrm{n}(\%)$ & & & & $n(\%)$ & & & \\
\hline Any drug & $59(48.8)$ & $1.91(0.65-5.62)$ & $1.41(0.49-4.08)$ & $1.53(0.66-3.53)$ & $25(39.7)$ & $2.22(0.45-10.9$ & $2.27(0.79-6.49$ & $0.91(0.22-3.78)$ \\
\hline Any intravenous drug & $1(0.8)$ & $\S$ & $\S$ & $\S$ & $6(9.5)$ & $1.70(0.17-17.1)$ & $4.0(0.67-23.8)$ & $0.89(0.09-8.65)$ \\
\hline Marijuana & $36(29.8)$ & $2.75(0.94-8.03)$ & $2.04(0.70-5.98)$ & $0.79(0.30-2.06)$ & $16(25.4)$ & $2.48(0.49-12.5)$ & $1.06(0.33-3.43)$ & $0.70(0.15-3.22)$ \\
\hline Crack & $8(6.7)$ & $\S$ & $0.92(0.11-8.05)$ & $2.95(0.47-18.6)$ & $9(14.3)$ & $1.00(0.11-9.44)$ & $20.8(2.4-180.8$ & $1.52(0.17-13.9$ \\
\hline Cocaine & $13(10.8)$ & $1.21(0.24-6.03)$ & $0.51(0.06-4.22$ & $2.54(0.64-10.2)$ & $1(1.6)$ & $\S$ & $\S$ & $\S$ \\
\hline Heroin & $1(0.8)$ & $\S$ & $\S$ & $\S$ & $6(9.5)$ & $1.70(0.17-17.1)$ & $4.0(0.67-23.8)$ & $0.89(0.09-8.65)$ \\
\hline "Poppers" & $25(20.7)$ & $1.33(0.39-4.56)$ & $0.87(0.23-3.33)$ & $1.41(0.53-3.75)$ & --- & ---- & --- & --- \\
\hline "Uppers" & $6(5.0)$ & $\S$ & $1.32(0.14-12.1)$ & $0.92(0.16-5.31)$ & --- & ---- & --- & --- \\
\hline Methamphetamine & --- & --- & --- & --- & $2(3.2)$ & $\S$ & $\S$ & $\S$ \\
\hline Any lifetime use & $\mathrm{n}(\%)$ & & & & $\mathrm{n}(\%)$ & & & \\
\hline Any intravenous drug & $18(14.9)$ & $2.37(0.65-8.62)$ & $1.04(0.21-5.19)$ & $1.25(0.41-3.84)$ & $34(54.0)$ & $1.16(0.24-5.65)$ & $2.79(0.94-8.27)$ & $0.54(0.12-2.41)$ \\
\hline Marijuana & $98(81.7)$ & $\S$ & $1.67(0.35-7.93)$ & $0.80(0.28-2.30)$ & $52(82.5)$ & $0.48(0.08-2.86)$ & $0.41(0.11-1.52)$ & $\S$ \\
\hline Crack & $38(60.3)$ & $2.16(0.40-11.6)$ & $1.96(0.47-8.22)$ & $0.70(0.23-2.13)$ & --- & -- & --- & --- \\
\hline Cocaine & $76(62.8)$ & $1.61(0.48-5.40)$ & $2.44(0.65-9.18)$ & $1.52(0.62-3.72)$ & ---- & --- & --- & --- \\
\hline $\begin{array}{l}\text { Crack, cocaine or } \\
\text { heroin }\end{array}$ & --- & --- & --- & --- & $51(80.9)$ & $0.26(0.05-1.34)$ & $1.94(0.47-8.03)$ & $0.50(0.06-4.47)$ \\
\hline "Poppers" & $86(71.1)$ & $1.90(0.51-7.13)$ & $0.47(0.16-1.37)$ & $1.63(0.61-4.38)$ & --- & -- & --- & --- \\
\hline “Uppers" & $47(38.8)$ & $1.38(0.46-4.10)$ & $1.01(0.33-3.05)$ & $0.80(0.34-1.89)$ & --- & -- & --- & ---- \\
\hline Methamphetamine & --- & --- & ---- & --- & $4(6.4)$ & $\S$ & $0.56(0.06-5.73)$ & $\S$ \\
\hline
\end{tabular}

Table 2: HIV: Human Immunodeficiency Virus; AIDS: Acquired Immunodeficiency Syndrome; OR: Odds Ratio; CI: Confidence Interval; poppers: Amyl Nitrites; uppers: Stimulants, Including Methamphetamines. aAirflow obstruction defined as a pre- or post-bronchodilator forced expiratory volume in 1 second (FEV1)/forced vital capacity (FVC) $<0.70$; moderate diffusion impairment defined as diffusing capacity for carbon monoxide (DLCO) $<60 \%$ predicted; radiographic emphysema defined as $>1 \%$ of lung voxels $<-950$ Hounsfield units. bSurvey questions differ between MACS and WIHS. Unavailable data represented with "--". cOdds ratio represents the increase in odds of the primary outcome for each $20 \%$ increase in the percentage of total study visits reporting recent drug use. $₫$ No observations available for analysis

\section{Conclusions}

In summary, we investigated recreational drug use characteristics and pulmonary function among HIV-infected men and women in the era of antiretroviral therapy, and observed an independent association between recent crack cocaine use and moderate diffusion impairment in women. Recreational drug use is common among those with HIV. Given the increasing prevalence of HIV, any potential relationship between drug use and the prevalence of chronic pulmonary diseases 
could have a significant impact on HIV and chronic disease management. Future studies aimed at addressing this question would benefit from detailed information regarding frequency and quantity of recreational drug use and the complicated exposure histories of multisubstance users.

\section{Acknowledgements}

During the preparation of this manuscript, Dr. Simonetti received fellowship support from the Ruth L. Kirschstein National Research Service Award (T32HP10002), administered by the Health Resources and Services Administration. The content of this manuscript is solely the responsibility of the authors and does not necessarily represent the official views of any organization.

Data in this manuscript were collected by the Multicenter AIDS Cohort Study (MACS) with centers (Principal Investigators) at: Johns Hopkins University Bloomberg School of Public Health (Joseph Margolick), U01-AI35042; Northwestern University (Steven Wolinsky), U01-AI35039; University of California, Los Angeles (Roger Detels), U01-AI35040; University of Pittsburgh (Charles Rinaldo), U01-AI35041; the Center for Analysis and Management of MACS, Johns Hopkins University Bloomberg School of Public Health (Lisa Jacobson), UM1-AI35043. The MACS is funded primarily by the National Institute of Allergy and Infectious Diseases (NIAID), with additional co-funding from the National Cancer Institute (NCI). Targeted supplemental funding for specific projects was also provided by the National Heart, Lung, and Blood Institute (NHLBI), and the National Institute on Deafness and Communication Disorders (NIDCD). MACS data collection is also supported by UL1-TR000424 (JHU CTSA). Website located at http://www.statepi.jhsph.edu/macs/ macs.html. The contents of this publication are solely the responsibility of the authors and do not represent the official views of the National Institutes of Health (NIH). Data in this manuscript were collected by the Women's Interagency HIV Study (WIHS). The contents of this publication are solely the responsibility of the authors and do not represent the official views of the National Institutes of Health (NIH). WIHS (Principal Investigators): U01-AI-103408; Connie Wofsy Women's HIV Study, Northern California (Ruth Greenblatt, Bradley Aouizerat, and Phyllis Tien); Southern California WIHS (Alexandra Levine and Marek Nowicki), U01-HD-032632 (WIHS I - WIHS IV). The WIHS is funded primarily by the National Institute of Allergy and Infectious Diseases (NIAID), with additional co-funding from the Eunice Kennedy Shriver National Institute of Child Health and Human Development (NICHD), the National Cancer Institute (NCI), the National Institute on Drug Abuse (NIDA), and the National Institute on Mental Health (NIMH). WIHS data collection was also supported by UL1-TR000004 (UCSF CTSA).

\section{References}

1. Palella FJ, Delaney KM, Moorman AC, Loveless MO, Fuhrer J, et al (1998) Declining morbidity and mortality among patients with advanced human immunodeficiency virus infection. HIV Outpatient Study Investigators. N Engl J Med 338: 853-860.

2. Mills EJ, Bärnighausen T, Negin J (2012) HIV and aging--preparing for the challenges ahead. N Engl J Med 366: 1270-1273.

3. Walensky RP, Paltiel AD, Losina E, Mercincavage LM, Schackman BR, et al. (2006) The survival benefits of AIDS treatment in the United States. J Infect Dis 194: 11-19.

4. Crothers K, Huang L, Goulet JL, Goetz MB, Brown ST, et al. (2011) HIV infection and risk for incident pulmonary diseases in the combination antiretroviral therapy era. Am J Respir Crit Care Med 183: 388-395.
5. Morris A, Crothers K, Beck JM, Huang L; American Thoracic Society Committee on HIV Pulmonary Disease (2011) An official ATS workshop report: Emerging issues and current controversies in HIV-associated pulmonary diseases. Proc Am Thorac Soc 8: 17-26.

6. Gingo MR, George MP, Kessinger CJ, Lucht L, Rissler B, et al. (2010) Pulmonary function abnormalities in HIV-infected patients during the current antiretroviral therapy era. Am J Respir Crit Care Med 182: 790-796.

7. George MP, Kannass M, Huang L, Sciurba FC, Morris A (2009) Respiratory symptoms and airway obstruction in HIV-infected subjects in the HAART era. PLoS One 4: e6328.

8. Diaz PT, King MA, Pacht ER, Wewers MD, Gadek JE, et al. (1999) The pathophysiology of pulmonary diffusion impairment in human immunodeficiency virus infection. Am J Respir Crit Care Med 160: 272-277.

9. Fitzpatrick ME, Gingo MR, Kessinger C, Lucht L, Kleerup E, et al. (2013) HIV infection is associated with diffusing capacity impairment in women. J Acquir Immune Defic Syndr 64: 284-288.

10. Crothers K, McGinnis K, Kleerup E, Wongtrakool C, Hoo GS, et al. (2013) HIV infection is associated with reduced pulmonary diffusing capacity. J Acquir Immune Defic Syndr 64: 271-278.

11. Gingo MR, He J, Wittman C, Fuhrman C, Leader JK, et al. (2014) Contributors to diffusion impairment in HIV-infected persons. Eur Respir J 43: 195-203.

12. Morris A, George MP, Crothers K, Huang L, Lucht L, et al. (2011) HIV and chronic obstructive pulmonary disease: is it worse and why? Proc Am Thorac Soc 8: 320-325.

13. Justice AC, Lasky E, McGinnis KA, Skanderson M, Conigliaro J, et al. (2006) Medical disease and alcohol use among veterans with human immunodeficiency infection: A comparison of disease measurement strategies. Med Care 44: S52-60.

14. Cofrancesco J, Scherzer R, Tien PC, Gibert CL, Southwell H, et al. (2008) Illicit drug use and HIV treatment outcomes in a US cohort. AIDS 22: 357-365.

15. Browning KK, Wewers ME, Ferketich AK, Diaz P (2013) Tobacco use and cessation in HIV-infected individuals. Clin Chest Med 34: 181-190.

16. Substance Abuse and Mental Health Services Administration (2010) Center for Behavioral Health Statistics and Quality. The NSDUH Report: HIV/AIDS and Substance Use. USA.

17. Remien RH, Goetz R, Rabkin JG, Williams JB, Bradbury M, et al. (1995) Remission of substance use disorders: gay men in the first decade of AIDS. J Stud Alcohol 56: 226-232.

18. Sullivan PF, Becker JT, Dew MA, Penkower L, Detels R, et al. (1993) Longitudinal trends in the use of illicit drugs and alcohol in the Multicenter AIDS Cohort Study. Addiction Research \& Theory 1: 279-290.

19. D'souza G, Matson PA, Grady CD, Nahvi S, Merenstein D, et al. (2012) Medicinal and recreational marijuana use among HIV-infected women in the Women's Interagency HIV Study (WIHS) cohort, 1994-2010. J Acquir Immune Defic Syndr 61: 618-626.

20. Pence BW, Thielman NM, Whetten K, Ostermann J, Kumar V, et al. (2008) Coping strategies and patterns of alcohol and drug use among HIV-infected patients in the United States Southeast. AIDS Patient Care STDS 22: 869-877.

21. Prentiss D, Power R, Balmas G, Tzuang G, Israelski DM (2004) Patterns of marijuana use among patients with HIV/AIDS followed in a public health care setting. J Acquir Immune Defic Syndr 35: 38-45.

22. Lim SH, Ostrow D, Stall R, Chmiel J, Herrick A, et al. (2012) Changes in stimulant drug use over time in the MACS: evidence for resilience against stimulant drug use among men who have sex with men. AIDS Behav 16: 151-158.

23. Mégarbane B, Chevillard L (2013) The large spectrum of pulmonary complications following illicit drug use: features and mechanisms. Chem Biol Interact 206: 444-451. 
Citation: Simonetti JA, Gingo MR, Kingsley L, Kessinger C, Lucht L, et al. (2014) Pulmonary Function in HIV-Infected Recreational Drug Users in the Era of Anti-Retroviral Therapy. J AIDS Clin Res 5: 365. doi:10.4172/2155-6113.1000365

Page 7 of 7

24. Wolff AJ, O'Donnell AE (2004) Pulmonary effects of illicit drug use. Clin Chest Med 25: 203-216.

25. Tetrault JM, Crothers K, Moore BA, Mehra R, Concato J, et al. (2007) Effects of marijuana smoking on pulmonary function and respiratory complications: a systematic review. Arch Intern Med 167: 221-228.

26. Pletcher MJ, Vittinghoff E, Kalhan R, Richman J, Safford M, et al. (2012) Association between marijuana exposure and pulmonary function over 20 years. JAMA 307: 173-181.

27. Kleerup EC, Koyal SN, Marques-Magallanes JA, Goldman MD, Tashkin DP (2002) Chronic and acute effects of "crack" cocaine on diffusing capacity, membrane diffusion, and pulmonary capillary blood volume in the lung. Chest 122: 629-638.

28. Miller A, Taub H, Spinak A, Pilipski M, Brown LK (1991) Lung function in former intravenous drug abusers: the effect of ubiquitous cigarette smoking. Am J Med 90: 678-684.

29. Drummond MB, Merlo CA, Astemborski J, Kalmin MM, Kisalu A, et al. (2013) The effect of HIV infection on longitudinal lung function decline among IDUs: a prospective cohort. AIDS 27: 1303-1311.

30. Detels R, Jacobson L, Margolick J, Martinez-Maza O, Muñoz A, et al. (2012) The multicenter AIDS Cohort Study, 1983 to â€|. Public Health 126: 196-198.

31. Barkan SE, Melnick SL, Preston-Martin S, Weber K, Kalish LA, et al. (1998) The Women's Interagency HIV Study. WIHS Collaborative Study Group. Epidemiology 9: 117-125.

32. Guidelines for the use of antiretroviral agents in HIV-infected adults and adolescents (2008) Department of Health and Human Services / Henry J. Kaiser Family Foundation Panel on Clinical Practices for the Treatment of HIV Infection.

33. Miller MR, Hankinson J, Brusasco V, Burgos F, Casaburi R, et al. (2005) Standardisation of spirometry. Eur Respir J 26: 319-338.

34. Macintyre N, Crapo RO, Viegi G, Johnson DC, van der Grinten CP, et al. (2005) Standardisation of the single-breath determination of carbon monoxide uptake in the lung. Eur Respir J 26: 720-735.

35. Hankinson JL, Odencrantz JR, Fedan KB (1999) Spirometric reference values from a sample of the general U.S. population. Am J Respir Crit Care Med 159: 179-187.
36. Neas LM, Schwartz J (1996) The determinants of pulmonary diffusing capacity in a national sample of U.S. adults. Am J Respir Crit Care Med 153: 656-664.

37. Leader JK, Zheng B, Rogers RM, Sciurba FC, Perez A, et al. (2003) Automated lung segmentation in X-ray computed tomography: development and evaluation of a heuristic threshold-based scheme. Acad Radiol 10: 1224-1236.

38. Müller NL, Staples CA, Miller RR, Abboud RT (1988) "Density mask". An objective method to quantitate emphysema using computed tomography. Chest 94: 782-787.

39. Gevenois PA, de Maertelaer V, De Vuyst P, Zanen J, Yernault JC (1995) Comparison of computed density and macroscopic morphometry in pulmonary emphysema. Am J Respir Crit Care Med 152: 653-657.

40. George MP, Champion HC, Gladwin MT, Norris KA, Morris A (2012) Injection drug use as a "second hit" in the pathogenesis of HIV-associated pulmonary hypertension. Am J Respir Crit Care Med 185: 1144-1146.

41. Dhillon NK, Li F, Xue B, Tawfik O, Morgello S, et al. (2011) Effect of cocaine on human immunodeficiency virus-mediated pulmonary endothelial and smooth muscle dysfunction. Am J Respir Cell Mol Biol 45: 40-52.

42. Sitbon O, Lascoux-Combe C, Delfraissy JF, Yeni PG, Raffi F, et al. (2008) Prevalence of HIV-related pulmonary arterial hypertension in the current antiretroviral therapy era. Am J Respir Crit Care Med 177: 108-113.

43. Tashkin DP, Simmons MS, Coulson AH, Clark VA, Gong H Jr (1987) Respiratory effects of cocaine "freebasing" among habitual users of marijuana with or without tobacco. Chest 92: 638-644.

44. Itkonen J, Schnoll S, Glassroth J (1984) Pulmonary dysfunction in 'freebase' cocaine users. Arch Intern Med 144: 2195-2197.

45. Weiss RD, Tilles DS, Goldenheim PD, Mirin SM (1987) Decreased single breath carbon monoxide diffusing capacity in cocaine freebase smokers. Drug Alcohol Depend 19: 271-276. 